\title{
ANALISA KOMPETENSI DALAM MENINGKATAN KEPUASAN KERJA DAN KINERJA KARYAWAN
}

\section{ANALYSIS OF COMPETENCE IN IMPROVING EMPLOYEE SATISFACTION AND EMPLOYEE PERFORMANCE}

\author{
Zulkifli $^{1}$, Zulfadli Hamzah ${ }^{2}$, Muhammad Arif ${ }^{3}$, Astri Ayu Purwati ${ }^{4}$ \\ Universitas Islam Riau ${ }^{1,2,3}$, Institut Bisnis dan Teknologi Pelita Indonesia ${ }^{4}$ \\ zulkiflirusby@yahoo.com ${ }^{1}$
}

\begin{abstract}
The lack of competency possessed by BMT employees in Pekanbaru City both related to the competence of sharia science and from business development competencies, lack of employee ability to manage or organize Islamic financial service cooperatives and the low level of job satisfaction possessed by BMT employees. This research method is a descriptive method with a quantitative approach. Data analysis technique used in this research is quantitative analysis using SEM (Structural Equation Modeling) model with PLS program. The population in this study were all BMT employees in the city of Pekanbaru. The number of samples in this study were 79 respondents. The results of this study indicate there is a direct influence between competencies on Job Satisfaction of BMT employees in Pekanbaru, there is a direct effect between satisfaction on the performance of BMT employees in Pekanbaru, there is no indirect effect between competencies on performance through job satisfaction of BMT employees in Pekanbaru. Through the results of this study it is expected that all BMTs in Pekanbaru to pay attention and be more focused on aspects of employee job satisfaction because the level of employee job satisfaction is very significant influence on the performance of BMT employees in Pekanbaru.
\end{abstract}

Keywords: Competence, Job Satisfaction and Employee Performance.

\begin{abstract}
ABSTRAK
Kurangnya kompetensi yang dimiliki oleh karyawan BMT yang ada di Kota Pekanbaru baik itu yang berkaitan dengan kompetensi ilmu syariahnya maupun dari kompetensi pengembangan bisnisnya, kurangnya kemampuan karyawan dalam memenej atau mengorganisir koperasi jasa keuangan syariah dan tingkat kepuasan kerja yang masih rendah yang di miliki oleh karyawaan BMT. Metode penelitian ini adalah metode deskriptif dengan pendekatan kuantitatif. Teknik analisis data yang digunakan dalam penelitian ini adalah analisis kuantitatif dengan menggunakan model SEM (Structural Equation Modeling) dengan program PLS. Populasi dalam penelitian ini adalah seluruh Karyawan BMT yang ada di Kota Pekanbaru. Adapun jumlah sampel dalam penelitian ini adalah 79 responden. Hasil penelitian ini menunjukkan terdapat pengaruh langsung antara kompetensi terhadap Kepuasan Kerja karyawan BMT di Pekanbaru, terdapat pengaruh langsung antara kepuasan terhadap kinerja karyawan BMT di Pekanbaru, tidak terdapat pengaruh secara tidak langsung antara kompetensi terhadap kinerja melalui kepuasan kerja karyawan BMT di Pekanbaru. Melalui
\end{abstract}


hasil penelitian ini diharapkan kepada seluruh BMT yang ada di Kota Pekanbaru untuk memperhatikan dan lebih terfokus pada aspek kepuasan kerja karyawan karena tingkat kepuasan kerja karyawan sangat berpengaruh signifikan terhadap kinerja karyawan BMT yang ada di kota Pekanbaru.

Kata Kunci : Kompetensi, Kepuasan Kerja dan Kinerja Karyawan.

\section{PENDAHULUAN}

Koperasi menurut Undangundang No. 17 Tahun 2012 adalah badan hukum yang didirikan oleh orang perseorangan atau badan hukum Koperasi, untuk dengan pemisahan kekayaan para anggotanya sebagai modal menjalankan usaha, yang memenuhi aspirasi dan kebutuhan bersama di bidang ekonomi, sosial, dan budaya sesuai dengan nilai dan prinsip Koperasi.

Salah satu jenis atau bentuk koperasi adalah Koperasi Jasa Keuangan syariah yang bergerak dalam bidang simpan pinjam syariah yang juga meliputi kegiatan pembiayaan, investasi, dan simpanan yang sistemnya sesuai pola bagi hasil (syariah). Menurut Peraturan Menteri Negara Koperasi dan Usaha Kecil dan Menengah Republik Indonesia No. $\quad 35.3 / P e r / M . K U K M / X / 2007$, KJKS adalah koperasi yang kegiatan usahanya bergerak dibidang pembiayaan, investasi, dan simpanan dengan pola syariah.Dan salah satu bentuk perwujudan dan eksistensi Koperasi Jasa keuangan Syariah yang lebih familiar atau dikenal dengan istilah Baitul Mall Wat tamwil (BMT).

Kota Pekanbaru adalah ibukota provinsi Riau yang mayoritas penduduknya beragama Islam dan berbudaya melayu dengan luas wilayah 8.915.016 KM2 dan jumlah penduduk 1,2 juta jiwa (2018) yang sebagian besar penduduknya bekerja di sektor jasa dan perdagangan. Dalam beberapa tahun terakhir kota pekanbaru mengalami perkembangan yang pesat baik itu dari sektor pembangunan maupun sektor perekonomian. Sehingga ini menjadi potensi yang besar untuk perkembangan BMT yang ada di Kota pekanbaru.

Keberhasilan suatu organisasi tidak terlepas dari peningkatan sumber daya manusia. Sumber daya manusia yang unggul dan berkualitas harus selalu dikelola dan ditekankan oleh organisasi untuk dapat mencapai kinerja yang diharapkan. Oleh karena itu, peningkatan kualitas sumber daya manusia sangat diperlukan agar karyawan memiliki sifat dan perilaku yang mampu memberikan pelayanan dan pengayoman serta memberikan kesejahteraan lahir batin bagi masyarakat (Harjanto 2015).

Kinerja karyawan yang tinggi sangatlah diharapkan oleh BMT karenasemakin banyak karyawan yang mempunyai kinerja tinggi, maka produktifitas BMT secara keseluruhan juga akan meningkat sehingga BMT akan dapat bertahan dalam persaingan global terutama pada era MEA (Masyarakat Ekonomi Asean) sekarang ini. Adapun faktorfaktor yang dapat mempengaruhi kinerja karyawan BMT di antaranya adalah Kompetensi, dan Kepuasan Kerja Karyawan.

Dari fenomena yang terjadi di dapati masih rendahnya kualitas dan kinerja karyawan BMT yang ada di 
Kota Pekanbaru, hal ini sesuai dengan hasil peneliitan yang dilakukan oleh Hamzah et al., (2013). Terdapat beberapa faktor penyebab rendahnya kualitas dan kinerja karyawan di antaranya adalah kurangnya kompetensi yang dimiliki baik itu yang berkaitan dengan kompetensi ilmu syariahnya maupun dari kompetensi pengembangan bisnisnya, kurangnya kemampuan karyawan dalam memenej atau mengorganisir koperasi jasa keuangan syariah dan tingkat kepuasan kerja yang masih rendah yang di miliki oleh karyawan. Selanjutnya penelitian Pramularso (2018) yang hasil penelitiannya menemukan bahwa kompetensi berpengaruh positif dan signifikan terhadap Kinerja Karyawan. Deswarta (2017) hasil penelitianya juga menemukan bahwa kompetensi berpengaruh positif dan signifkan terhadap Kepuasan kerja.

Berdasarkan fenomena kinerja di atas yang di dasari oleh beberapa penelitian terdahulu maka penelitian ini berfokus untuk memberikan solusi kepada kinerja karyawan BMT, yang mana dari telaah penelitian yang dilakukan belum ada penelitian yang mencoba memberikan penyelesaian terhadap kinerja karyawan BMT, kebanyakan penelitian tentang BMT adalah seputar peningkatan kinerja bisnisnya. Selanjutnya juga penelitian ini mencoba memastikan kembali pengaruh dari kompetensi yang dimiliki individu apakah benar akan berdampak terhadap kepuasan dan kinerja dari individu tersebut dimana penelitian-penelitian sebelumnya masih terdapat perbedaan hasil penelitan.

\section{METODE PENELITIAN}

Penelitian ini dilaksanakan di Kota Pekanbaru kepada seluruh Baitul Maal Wat Tamwil (BMT) yang ada di Kota Pekanbaru. Populasi dalam penelitian ini adalah seluruh Karyawan Baitul Maal Wat Tamwil (BMT) yang ada di Kota Pekanbaru.Sampel adalah bagian dari jumlah dan karakteristik yang dimiliki oleh populasi tersebut. Maka metode sampling yang digunakan dalam penelitian ini adalah total sampling (sensus) dengan jumlah responden sebanyak 79 responden.

Model yang digunakan dalam penelitian ini adalah model kausalitas atau hubungan pengaruh.Untuk menguji hipotesis yang diajukan, digunakan teknik analisis SEM (stuctural equation model).Penelitian ini menggunakan SEM karena teknik multivariat yang menggabungkan aspek regresi berganda dan analisis faktor untuk mengestimasi rangkaian hubungan ketergantungan yang saling berhubungan secara simultan.

Dalam penelitian ini analisis data menggunakan pendekatan Partial Least Square (PLS). PLS adalah model persamaan struktural (SEM) yang berbasis komponen atau varian (variance). PLS merupakan pendekatan alternatif yang bergeser dari pendekatan SEM berbasis covariance menjadi berbasis variance. SEM yang berbasis kovarian umumnya menguji kausalitas atau teori, sedangkan PLS lebih bersifat predictive model. PLS merupakan metode analisis yang powerfull, karena tidak didasarkan pada banyak asumsi. Misalnya, data harus terdistribusi secara normal, sampel tidak harus besar. Selain dapat digunakan untuk mengkonfirmasi teori, PLS juga 
dapat digunakan untuk menjelaskan ada tidaknya hubungan antara variabel laten.

\section{HASIL DAN PEMBAHASAN}

Analisis Partial Least Square (PLS)

Dalam penelitian ini analisis data menggunakan pendekatan Partial Least Square (PLS) yang menggunakan software smartPLS. Partial Least Square (PLS) adalah model persamaan struktural (SEM) yang berbasis komponen variance. Pendekatan PLS adalah distribution free (tidak menggunakan data berdistribusi tertentu, dapat berupa nominal, kategori, ordinal, interval maupun rasio). Selain itu PLS juga dapat digunakan untuk mengukur sampel yang jumlahnya kecil.

Berikut ini tahap-tahap menggunakan pendekatan Least Square (PLS) dengan menggunakan software smartPLS:

\section{Convergent Validity}

Convergent Validity adalah model pengukuran dengan indikator refleksif berdasarkan korelasi antara skor item dan skor komponen dengan PLS. Nilai factor loading hanya melihat hubungan antar indikator dengan konstruk eksogen. Nilai loading faktor yang $<0,5$ harus dikeluarkan dari model dan dilakukan estimasi ulang nilai factor loading. Dengan mengeluarkan beberapa nilai loading faktor $<0,5$ maka hasil bagi seluruh item pernyataan atau manifest dalam penelitian ini telah memenuhi convergant validity karena semua factor loading > 0.5. Dengan demikian, dapat disimpulkan convergant validity dari seluruh kelompok konstruk endogen adalah valid.

\section{Discriminant Validity}

Model dikatakan mempunyai discriminant validity yang baik jika setiap nilai loading indikator dari sebuah variabel laten lebih besar berkorelasi dengan variabel laten tersebut dibanding bila dikorelasikan dengan variabel laten lainnya.

Nilai loading factor untuk setiap indikator dari masing-masing variabel laten memiliki nilai loading factor yang paling besar dibanding nilai loading factor jika dihubungkan dengan variabel laten lainnya. Hal ini berarti bahwa setiap variabel laten memiliki discriminant validity yang baik

\section{Uji Reliabilitas}

Tahapan selanjutnya adalah pengujian konsitensi pengukuran (reliabilitas) dengan Average Variance Extract (AVE) dan Composite Realiability (CR).Reliabilitas tinggi menunjukkan bahwa indikatorindikator mempunyai konsistensi tinggi dalam mengukur konstruk latennya. Reliabilitas dapat diketahui melalui nilai Composite Reliability (CR) dan Average Variance Extracted (AVE).Composite reliability dikatakan baik bila memiliki nilai $\geq 0$.7.Nilai AVE dikatakan baik bila memiliki nilai $\geq$ 0.5 (Ghozali, 2009). Data hasil pengujian AVE dan CR ditunjukkan pada tabel 1 berikut ini. 
Tabel 1. Reliabilitas Konstruk

\begin{tabular}{|c|c|c|c|c|}
\hline Variabel & $\begin{array}{l}\text { Cronbach's } \\
\text { Alpha }\end{array}$ & $\begin{array}{l}\text { Composite } \\
\text { Reliability }\end{array}$ & $\begin{array}{l}\text { Average Variance } \\
\text { (AVE) }\end{array}$ & Extracted \\
\hline Kepuasan & 0.864 & 0.890 & 0.606 & \\
\hline Kinerja & 0.760 & 0.826 & 0.584 & \\
\hline Kompetensi & 0.873 & 0.900 & 0.533 & \\
\hline
\end{tabular}

Sumber : Data Olahan (2019)

Berdasarkan hasil uji validitas dan reliabilitas dari model pengukuran, dapat disimpulkan bahwa semua variable teramati valid mengukur variabel latennya, dan realiabilitas model pengukurannya pun baik.Hal ini menunjukkan bahwa indikator reliable dalam menyusun konstruk eksogen.

\section{Pengujian Model Struktural (Inner Model)}

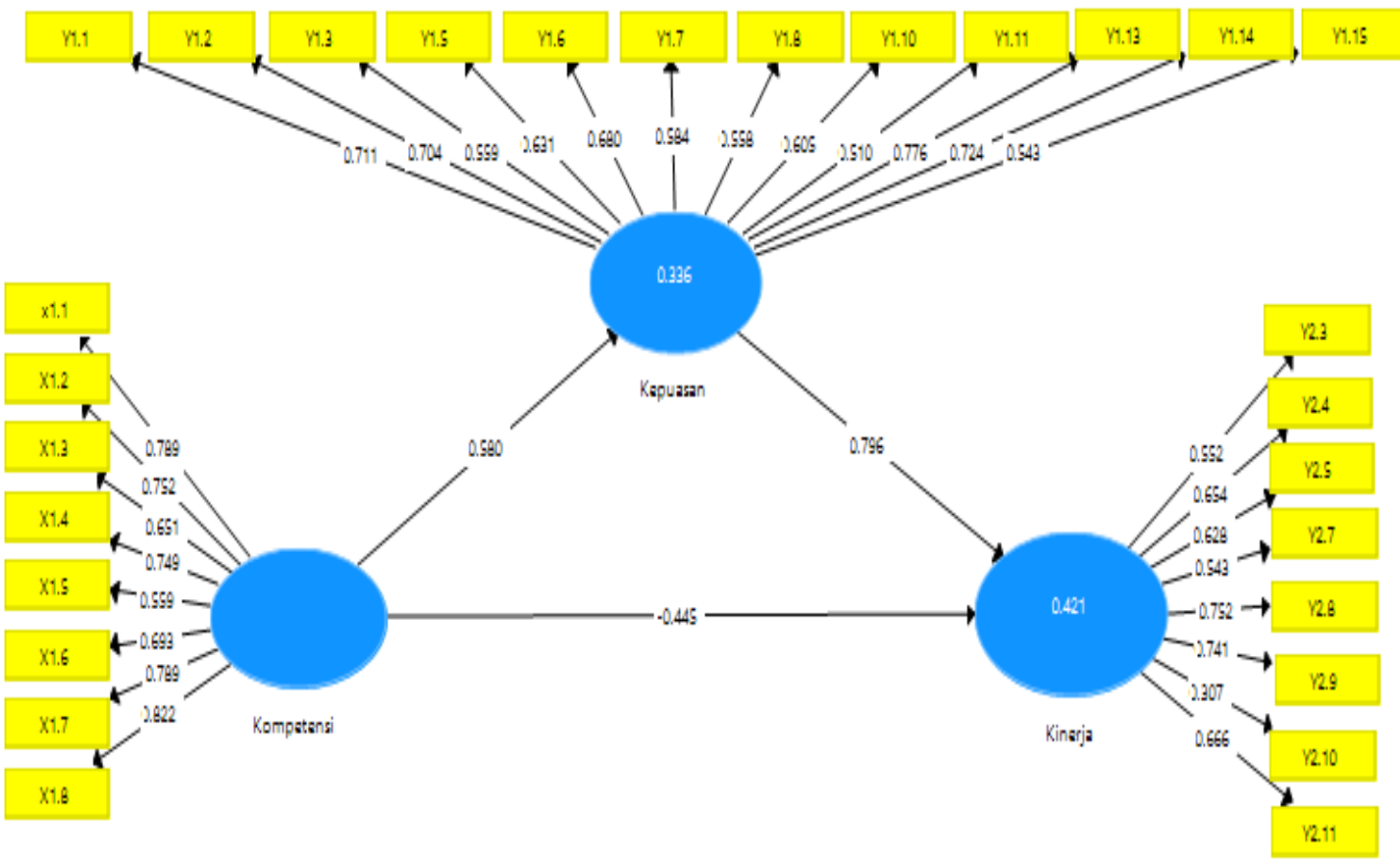

Gambar 1. Model Path

Tabel 2 Pengujian R Square

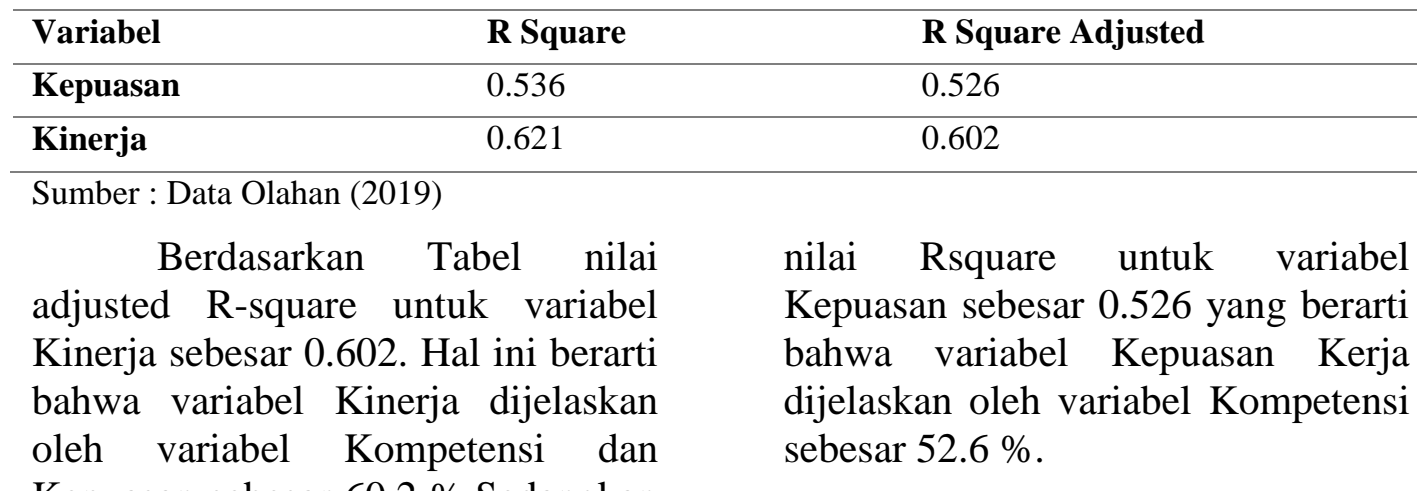

Kepuasan sebesar $60.2 \%$.Sedangkan 


\section{Pengujian Hipotesis}

Tabel 3. Koefisien Path

\begin{tabular}{|c|c|c|c|c|c|c|c|}
\hline & & $\begin{array}{l}\text { Original } \\
\text { Sample } \\
(\mathbf{O})\end{array}$ & $\begin{array}{l}\text { Sample } \\
\text { Mean } \\
(\mathrm{M})\end{array}$ & $\begin{array}{l}\text { Standard } \\
\text { Deviation } \\
\text { (STDEV) }\end{array}$ & $\begin{array}{l}\text { T Statistics } \\
(|\mathrm{O} / \mathrm{STDEV}|)\end{array}$ & P Values & Ket \\
\hline $\begin{array}{l}\text { Kompetensi } \\
\text { Kinerja }\end{array}$ & $->$ & -0.445 & -0.357 & 0.286 & 1.559 & 0.120 & No Sig \\
\hline $\begin{array}{l}\text { Kompetensi } \\
\text { Kepuasan }\end{array}$ & $->$ & 0.580 & 0.514 & 0.344 & 1.684 & $0.093^{*}$ & Sig 0.1 \\
\hline $\begin{array}{l}\text { Kepuasan } \\
\text { Kinerja }\end{array}$ & $->$ & 0.796 & 0.776 & 0.269 & 2.957 & $0.003 * * *$ & Sig 0.01 \\
\hline $\begin{array}{l}\text { Kompetensi } \\
\text { Kepuasan } \\
\text { Kinerja_ }\end{array}$ & $\begin{array}{l}-> \\
->\end{array}$ & 0.461 & 0.402 & 0.325 & 1.420 & 0.156 & No Sig \\
\hline
\end{tabular}

Berdasarkan tabel di atas maka hipotesis penelitian yang diperoleh adalah sebagai berikut :

H1.Terdapat pengaruh langsung antara kompetensi terhadap kinerja karyawan BMT di Pekanbaru

Dari hasil analisa statistik hasil uji $\mathrm{T}$ menunjukkan angka sebesar $1.559<\mathrm{T}$ tabel 1.67 dan nilai $\mathrm{P}$ Value menunjukkan perolehan $0.120>\alpha \quad 0.1$ maka dapat disimpulkan $\mathrm{H} 1$ ditolak dan artinya tidak terdapat pengaruh langsung antara kompetensi terhadap kinerja karyawan BMT di Pekanbaru.

H2.Terdapat pengaruh langsung antara kompetensi terhadap Kepuasan Kerja karyawan BMT di Pekanbaru

Dari hasil analisa statistik hasil uji $\mathrm{T}$ menunjukkan angka sebesar $1.684>\mathrm{T}$ tabel 1.67 dan nilai $\mathrm{P}$ Value menunjukkan perolehan $0.093<\alpha \quad 0.1$ maka dapat disimpulkan $\mathrm{H} 2$ diterima dan terdapat pengaruh kompetensi terhadap kepuasan karyawan BMT di Pekanbaru
H3.Terdapat pengaruh langsung antara kepuasan terhadap kinerja karyawan BMT di Pekanbaru

Dari hasil analisa statistik hasil uji $\mathrm{T}$ menunjukkan angka sebesar $2.957>$ T tabel 2.65 dan nilai $\mathrm{P}$ Value menunjukkan perolehan $0.003<\alpha 0.01$ maka dapat disimpulkan $\mathrm{H} 1$ diterima dan terdapat pengaruh langsung antara kepuasan terhadap kinerja karyawan BMT di Pekanbaru

H4.Terdapat pengaruh tidak langsung antara kompetensi terhadap kinerja melalui kepuasan kerja karyawan BMT di Pekanbaru

Dari hasil analisa statistik hasil uji $\mathrm{T}$ menunjukkan angka sebesar $1.420<\mathrm{T}$ tabel 1.67 dan nilai $\mathrm{P}$ Value menunjukkan perolehan $0.156>\alpha \quad 0.1$ maka dapat disimpulkan $\mathrm{H} 4$ ditolak dan artinya tidak terdapat pengaruh tidak langsung antara kompetensi terhadap kinerja melalui kepuasan kerja karyawan BMT di Pekanbaru. 


\section{Pengaruh Kompetensi terhadap Kinerja Karyawan}

Kompetensi yang dimiliki oleh seseorang merupakan dimensi perilaku yang ada dibelakang kinerja kompeten yang menunjukan bagaimana orang berperilaku ketika mereka menjalankan perannya dengan baik (Pomalingo, 2015). Kompetensi ini adalah karakteristik dasar personel yang menjadi faktor penentu sukses tidaknya seseorang dalam mengerjakan suatu pekerjaan atau pada situasi tertentu (Permanasari et al., 2019). Melalui kompetensi, seseorang dapat i gambaran tentang apa yang harus diketahui atau dilakukan seseorang agar dapat melaksanakan pekerjaannya dengan baik (Irawan 2017).

Hasil Penelitian ini menunjukkan bahwa kompetensi tidak berpengaruh signifikan terhadap terhadap kinerja karyawan BMT yang ada di kota Pekanbaru dengan nilai $\mathrm{P}$ value sebesar $0.120>$ $\alpha$ 0.1. Hasil penelitian ini bertentangan dengan penelitian yang dilakukan oleh Pramularso (2018) yang hasil penelitiannya menemukan bahwa kompetensi berpengaruh positif dan signifikan terhadap Kinerja Karyawan.

\section{Pengaruh Kompetensi terhadap Kepuasan Kerja Karyawan}

Kepuasan Kerja didefinisikan sebagai keadaan yang menyenangkan atau emosi positif yang dihasilkan dari penilaian pekerjaan atau pengalaman kerja seseorang. Kepuasan kerja dihasilkan dari presepsi karyawan mengenai seberapa baik pekerjaan mereka menyediakan hal yang dipandang Penting.

Hasil penelitian ini menunjukkan bahwa kompetensi berpengaruh positif dan signifikan terhadap Kepuasan kerja karyawan BMT yang ada di Kota Pekanbaru dengan nilai $\mathrm{P}$ value sebesar $0.093<$ $\alpha$ 0.1. Hasil penelitian ini sama dengan penelitian yang dilakukan oleh Deswarta (2017) yang hasil penelitianya menemukan bahwa kompetensi berpengaruh positif dan signifkan terhadap Kepuasan kerja. Hal ini sesuai dengan teori dari Lawler yang menyatakan bahwa keahlian menjadi bagian dari faktor masukan yang mempengaruhi kepuasan kerja atau ketidakpuasan dalam Sukamto \& Pardjono (2016).

\section{Pengaruh Kepuasan Kerja terhadap Kinerja Karyawan}

Kepuasan kerja merupakan salah satu faktor yang sangat penting untuk mendapatkan hasil kerja yang optimal. Ketika seseorang merasakan kepuasan dalam bekerja tentunya ia akan berupaya semaksimal mungkin dengan segenap kemampuan yang dimilikinya untuk menyelesaikan tugas atau pekerjaannya. Kemudian setelah mendapatkan kepuasan kerja akan sangat penting untuk meningkatkan kompetensi, tujuannya adalah supaya setiap pekerjaannya dapat dikerjakan dengan baik.

Hasil penelitian ini menunjukkan bahwa Kepuasan Kerja berpengaruh positif dan signifikan terhadap Kinerja Karyawan BMT yang ada di Kota Pekanbaru dengan nilai $\mathrm{P}$ value sebesar $0.003<\alpha 0.01$. Hasil penelitian ini sama dengan penelitian yang dilakukan oleh Arif (2019) yang hasil penelitiannya menemukan bahwa Kepuasan Kerja berpengaruh positif dan signifikan terhadap Kinerja karyawan Divisi Mikro Mitra Usaha Rakyat (MUR) PT. Bank BTPN cabang Pekanbaru. Hasil penelitian ini juga sama dengan 
penelitian yang dilakukan oleh Rusby \& Hamzah (2017) yang hasil penelitiannya menemukan bahwa kepuasan Kerja berpengaruh positif dan signifikan terhadap Kinerja karyawan.

\section{PENUTUP}

\section{Kesimpulan}

Kompetensi

tidak

berpengaruh signifikan terhadap kinerja karyawan BMT yang ada di kota pekanbaru. Ini berarti untuk meningkatkan kinerja karyawan BMT yang ada di kota pekanbaru tidak perlu di buatnya program pelatihan, pendidikan maupun workshop untuk peningkatan kompetensi karyawan BMT yang ada di Kota Pekanbaru. Hal ini juga berarti bahwa kompetensi karyawan BMT yang ada sekarang sudah sesuai dengan apa yang di butuhkan oleh BMT.

Kompetensi berpengaruh positif dan signikan terhadap kepuasaan kerja. Ini berarti untuk meningkatkan kepuasan kerja karyawan BMT yang ada di kota pekanbaru perlu adanya peningkatan pada kompetensi karyawan BMT yang ada di Kota pekanbaru. Kepuasan kerja merupakan salah satu faktor yang sangat penting untuk mendapatkan hasil kerja yang optimal.

Kepuasan Kerja berpengaruh positif dan signifikan terhadap kinerja karyawan. Ini berarti semakin meningkat kepuasan kerja karyawan maka semakin meningkat pula kinerja karyawan BMT yang ada di kota Pekanbaru. Oleh karena itu untuk meningkatkan kinerja karyawan BMT yang ada dikota pekanbaru, Maka masing-masing
BMT harus meningkatkan lagi kepuasan kerja karyawannya.

\section{Saran}

Di harapkan kepada seluruh BMT yang ada di Kota Pekanbaru untuk memperhatikan dan lebih terfokus pada aspek kepuasan kerja karyawan karena tingkat kepuasan kerja karyawan sangat berpengaruh signifikan terhadap kinerja karyawan BMT yang ada di kota Pekanbaru. Salah satu faktor yang dapat meningkatkan kepuasan kerja karyawan adalah dengan peningkatan kompetensi yang di miliki oleh karyawan BMT.

Bagi peneliti lainnya, Penelitian ini sebagai acuan untuk melakukan penelitian lebih mendalam lagi mengenai Kompetensi, Kepuasan Kerja dan Kinerja Karyawan BMT yang ada di Kota Pekanbaru dari segala aspek.

\section{DAFTAR PUSTAKA}

Arif, M. (2019). The Effect of Managerial Competencies, Compesation and Career Planning Toward Employee Performance Through Job Satisfaction at PT. Bank BTPN Tbk Mikro Banking Division (MUR) Pekanbaru Branch. Journal of Management Info (JMI). 6(1), 17-21.

Deswarta. (2017). Pengaruh Kompetensi dan Motivasi terhadap Kepuasan Kerja dan Kinerja Dosen Fakultas Tarbiyah dan Keguruan UIN Sultan Syarif Kasim Riau. Jurnal Valuta, 3(1).

Harjanto, E. (2015). Pengaruh Motivasi Berprestasi Dan Kompetensi Pedagogik Terhadap Kinerja Mengajar 
Guru. Jurnal Manajemen

Pendidikan, 24(5), 456-466.

Hamzah, Rusby, Z. \& Hamzah, Z. (2013). Analysis Problem of Baitul Maal Wat Tamwil (BMT) Operation in Pekanbaru Indonesia Using Analytical Network Process (ANP) Approach. International Journal of Academic Research in Business and Social Sciences. 3(8).

Irawan, B. (2017). Pengaruh Kompetensi Dan Lingkungan Kerja Terhadap Kinerja Karyawan Pada Pt. Presol Indo Prima Palembang. MOTIVASI:

Jurnal Manajemen dan Bisnis, 1(1), 1-12.

Pramularso, E.Y. (2018). Pengaruh Kompetensi terhadap Kinerja Karyawan CV Inaura Anugerah Jakarta. Widya Cipta, 2(1),40-46.

Pomalingo, R. (2015). Pengaruh Disiplin Kerja, Kompetensi, dan Motivasi Terhadap Kinerja Pegawai pada Kantor Badan Penanggulangan Bencana Daerah Provinsi Sulawesi Utara. Jurnal Berkala Ilmiah Efisiensi, 15(5).

Permanasari, R., Setyaningrum, R. M., \& Sundari, S. (2019). Model Hubungan Kompetensi, Profesionalisme dan Kinerja Dosen. JBMP (Jurnal Bisnis, Manajemen dan Perbankan), 1(2), 157174. 